\section{A de Man}

Dr A de Man, Coordinator:

Advocacy Division, Free

State Centre for Human

Rights, University of the

Free State.

DOl: https://dx.doi.

org/10.18820/24150517/

JJS43.v1.5

ISSN 0258-252X (Print) ISSN 2415-0517 (Online)

Journal for Juridical

Science

2018 43(1):84-116

(C) UV/UFS

\section{Critiques of the human rights framework as the foundation of a human rights-based app- roach to development}

\begin{abstract}
During the 1990s, the human rights-based approach (HRBA) emerged as the newest development framework to address increasing global poverty and inequality. Under this approach, development objectives are determined by human rights standards and goals as set out in international treaties, conventions, declarations, and authoritative interpretations of rights. Beneficiaries of development programmes also gain legal rights against corresponding duty bearers, which supersedes moral claims for the fulfilment of development goals. Furthermore, human rights principles such as equality and non-discrimination, accountability, participation, empowerment and the indivisibility of rights form the cornerstone of a HRBA. However, the human rights framework, as the foundation for this approach, has come under severe criticism over the past few years. Significant disparities exist between that which is promised in the Universal Declaration of Human Rights and real-world respect for, and protection of human rights. This article aims to explore and analyse the most popular of these criticisms. These include critiques raised against the claimed universality of rights, inherent discriminatory practices, the inability of the framework to take account of practicalities and limitations, and the lack of effective protection and monitoring by United Nation's bodies. It also explores emerging threats such as, for example, globalisation to the human rights framework. However, the framework has proven to be adaptable to these challenges. Practitioners and scholars are continuously working towards overcoming practicalities that impede the achievement of the protection and realisation of the human rights of all. In addition, the article examines critiques against the normative value of human rights as a product of natural law. However, the international human rights framework has gained widespread acceptance as the highest moral authority, as it is based on respect for human dignity and guaranteeing the freedom of all. The article demonstrates that the use of human rights language in lieu of other terms such as 'goals', 'duties', 'interests', 'needs', and 'claims' carries several advantages, the most important of which is the creation of rights holders with corresponding duty bearers. It also determines that, despite the numerous critiques examined, the human rights framework offers a solid, and the most accepted, foundation for development programming with a number of benefits.
\end{abstract}

\section{Introduction}

Traditionally, theories of development focused mainly on achieving economic progress, with limited focus on human 
welfare. ${ }^{1}$ Under the more modern view, it is held that "development is an integrated process of change involving intertwined economic, social, cultural, political, and environmental dimensions". ${ }^{2}$ However, under the auspices of the United Nations (UN), the focus slowly shifted to the impact of development on human beings, and improving their well-being. ${ }^{3} \operatorname{In} 2000$, UN member states adopted the Millennium Development Goals (MDGs), which offered the world a global compact on development priorities, with the eradication of poverty and inequality as the focus of international development. The year 2015 was proposed as the deadline for the achievement of these Goals. ${ }^{4}$ Unfortunately, not all the Goals proposed under the MDG framework were achieved. ${ }^{5}$ The limited role that human rights played in the formulation and implementation of the Goals was put forth as one of the reasons for its failure. ${ }^{6}$ It was subsequently proposed that any follow-up agenda ${ }^{7}$ should be based on the international human rights framework. ${ }^{8}$ Former UN High Commissioner for Human Rights, Mary Robinson, stated that the post-2015 development goals "must be rooted on human rights and the rule of law and governance issues to ensure progress". 9

In answer to this, many scholars and practitioners in the field of either human rights or development have advocated for a human rights-based approach to development (HRBAD) to underscore the post-2015 agenda. ${ }^{10}$ Indicative of the UN's strong support for an integrated relationship between human rights and development, the 2000 Human Development Report, published by the UN Development Programme (UNDP) affirmed that "human development is essential for realising human rights, and human rights are essential for full human development". ${ }^{11}$ Under a HRBAD, development objectives, including the processes whereby they are achieved, are determined by human rights standards and goals, as contained in the Universal Declaration of Human Rights (UDHR) ${ }^{12}$ and other international human rights treaties, conventions, and declarations. ${ }^{13}$ By the end of the

\footnotetext{
Arndt 2008:54; Bradlow 2004:195.

Bradlow 2004:195.

See, for instance, UNDP 1990; Anan 2000; Jackson 2007; Bhouraskar 2013.

See UNGA 2000; UN 2016.

See UN 2015:4-7.

See Langford et al. 2013b:3-5.

7 The 2030 Agenda for Sustainable Development was adopted on 25 September 2015 and came into effect on 1 January 2016.

$8 \quad$ Glendinning 2013:301.

9 Anonymous 2013.
}

10 See, for instance, UN Systems Task Team on the Post-2015 UN Development Agenda 2012:23-25; Joint Statement from 332 Civil Society Organizations 2013; UNGA 2013:par. 75; Knox 2015:517, 524; MacNaughton \& Frey 2016:644-646.

11 UNDP 2000:2.

12 UNGA 1948.

13 For instance, the United Nations International Covenant on Economic, Social and Cultural Rights (1966); the United Nations Declaration on the Right to Development (1986); the United Nations Convention on the Rights of the Child (1989). 
1990s, a large number of non-governmental organisations (NGOs), national and international development organisations, and human rights bodies advocated for a HRBAD, especially in the run-up to the 1995 Copenhagen Summit on Social Development. ${ }^{14}$ To date, the HRBAD has been adopted by several UN agencies, in particular the UNDP, and governments such as, for example, the United Kingdom, Sweden, Denmark, and Norway. ${ }^{15}$ NGOs such as ActionAid, CARE, OXFAM and Save the Children, as well as several inter-governmental organisations and bilateral donors have embraced this approach throughout their development initiatives. ${ }^{16}$

However, support for the international human rights framework has started to diminish over the past few years. Many practitioners have lost faith in the implementation value of human rights, whilst various authors such as Douzinas ${ }^{17}$ and Hopgood ${ }^{18}$ have questioned the moral and/or legal foundation of this grand notion of entitlements.

It thus falls to be questioned: If our international development priorities are based on a HRBAD, what are the operational and normative critiques that have been raised against the human rights framework as the foundation of this approach? This article will commence with a brief overview of a HRBAD, whereafter it will explore and analyse critiques against the human rights framework.

\section{What is a rights-based approach to development?}

Following the UN's recognition of the right to development in $1986,{ }^{19}$ and heavy criticism of the welfare model to development, rights language slowly made its way into the operational framework and objectives of development agencies. The HRBAD ultimately came to the fore in the 1990 s. $^{20}$ The UN Office of the High Commissioner for Human Rights (OHCHR) defined a HRBAD as "a conceptual framework for the process of human development that is normatively based on international human rights standards and operationally directed to promoting and protecting human rights". ${ }^{21}$ This approach establishes a moral and legal basis for the goals of development. ${ }^{22}$ It also empowers individuals and communities to participate in development processes that affect their lives, hold duty bearers accountable, assert their rights, and demand justice, not as charity, but as a claim to which they are legally entitled. ${ }^{23}$ A HRBAD "puts

14 Cornwall \& Nyamu-Musembi 2004:1423-1424.

15 Kindornay et al. 2012:479, 481.

16 Filmer-Wilson 2005:216; Darrow \& Tomas 2005:479-480; Kindornay et al. 2012:479-480; Ely Yamin 2008:45.

17 See Douzinas 2000.

18 See Hopgood 2013.

19 UNGA 1986.

20 Mitlin \& Hickey 2009:6.

21 OHCHR 2006a:15.

22 De Beco 2010:266.

23 Filmer-Wilson 2005:216-217. 
human rights at the heart of human development". ${ }^{24}$ At its core, a HRBAD "integrates the norms, standards, and principles of the international human rights system into the plans, policies and processes of development". ${ }^{25}$

It is agreed that there is no single or exclusive definition of a HRBAD. ${ }^{26}$ Different agencies, actors and organisations in both the development and human rights fields have varying interpretations of this concept and differing methodologies and practices in implementing it. ${ }^{27}$ However, in May 2003, the UN published a statement concerning The Human Rights Based-Approach to Development Cooperation: Towards a Common Understanding among UN Agencies. ${ }^{28}$ The report identifies three common elements to the differing approaches followed by various UN bodies: all development programming should further the realisation of rights; internationally agreed human rights standards should guide all development objectives and processes, and a HRBAD creates legal rights and correlating obligations for rights holders and duty bearers.

In addition to these common elements, a HRBAD seeks "to give tangible expression to human rights "principles"'.29 The varying methodologies under this approach share a number of core principles. ${ }^{30}$ The main principles on which a HRBAD is based are equality and non-discrimination; accountability; participation; empowerment, as well as indivisibility and interdependence of rights. It is important to highlight that the reason for integrating these principles into development is not to merely incorporate human rights standards as benchmarks for progress. These principles should be applied in such a manner as to assist and facilitate the realisation of rights throughout the entire development process. ${ }^{31}$ The human rights that underpin each principle are anchored in the international human rights framework. These rights are "non-negotiable, consistent and legitimate". ${ }^{32}$ Therefore, the core principles of a HRBAD are legally binding upon the states that have voluntarily ratified the treaties in which the specific rights and principles are included. ${ }^{33}$

According to Van Ginneken, there are various advantages to framing the post-2015 goals on a HRBAD, as it

24 Filmer-Wilson 2005:213.

25 Mokhiber 2001:158.

26 Lundström Sarelin 2007:475; Gready 2008:736; O’Dwyer \& Unerman 2010:454; Tsikata 2004:130; Gauri \& Gloppen 2012:486.

27 Lundström Sarelin 2007:475; Gready \& Ensor 2005:22; Cornwall \& NyamuMusembi 2004:1425; Frediani 2010:181-182; Miller 2010:916.

28 UN Development Group 2003.

29 Darrow \& Tomas 2005:497.

30 Kindornay et al. 2012:476-477.

31 Lundström Sarelin 2007:476; Oppong 2006:126; Fukuda-Parr et al. 2014:107; Von Engelhard 2010:1136; UN Development Group 2003; Kindornay et al. 2012:476-477; O’Dwyer \& Unerman 2010:454; Filmer-Wilson 2005:221; OHCHR 2006b:par. 7.

32 UNDP 2006:22.

33 Cornwall \& Nyamu-Musembi 2004:1417; Frediani 2010:182. 
contribute[s] to a holistic approach to eradicating poverty and promoting development ... Human rights standards may also assist in building social consensus and mobilising political commitments at the national, regional and international levels. The human rights approach also focuses on holding governments and other actors accountable for their actions, and by so doing promotes a more efficient use of resources (by promoting access to information and fighting corruption). Lastly, a human rights approach promotes and enhances the empowerment of those living in poverty, thus enabling them to fully assume their responsibilities within their families, communities and societies. ${ }^{34}$

Other advantages include addressing inequalities by challenging oppressive social structures and practices; ${ }^{35}$ strengthened accountability measures; ${ }^{36}$ provision of clear guidelines and standards; ${ }^{37}$ equitable and sustainable progress; ${ }^{38}$ more support and collaboration from different actors across a variety of fields; ${ }^{39}$ establishing a global responsibility for development; ${ }^{40}$ providing a normative framework and legitimacy to development goals; ${ }^{41}$ taking account of local context; ${ }^{42}$ holistic understanding of the multiple facets of development, ${ }^{43}$ and so on. Moreover, it has been argued that social development targets "take on a deeper meaning" when they are linked to recognised human rights. ${ }^{44}$ Since its acceptance, the HRBAD has taken on various forms and contexts, and has formed part of international and national development planning, as well as communitybased development initiatives. ${ }^{45}$ It is now common practice for a variety of development agencies to use human rights as a guideline in their policies and programming. ${ }^{46}$

\section{Critiques of the human rights framework}

Human rights "take a stand on certain fundamental entitlements of citizens, and they hold that these may be demanded as a matter of basic justice", and that everyone has the right to have both their freedoms and capabilities protected via corresponding duty bearers. ${ }^{47}$ However, in order for human rights to attain the best possible level of protection, and thereby contribute to its full potential to a HRBAD, it should be open to criticism and overly

34 Van Ginneken 2011:115.

35 Mitlin \& Hickey 2009:12.

36 Cornwall \& Nyamu-Musembi 2004:1417.

37 Schmidt-Traub 2009:79.

38 Van Ginneken 2011:115.

39 Ife 2008:37.

40 OHCHR 2002:par. 13.

41 Cornwall \& Nyamu-Musembi 2004:1416.

42 Darrow \& Tomas 2005:525-526.

43 OHCHR 2002:par. 12.

44 Midgley 2014:200.

45 Darrow \& Tomas 2005:472.

46 Tomalin 2006:93; OHCHR 2008:7.

47 Nussbaum 2000:241. See also Freeman 2011:71. 
idealistic accounts of human rights should be rejected, even by its most passionate advocates. ${ }^{48}$ It is evident that there is a large disparity between what is promised in the UDHR and real-world respect for, and protection of human rights. ${ }^{49}$ Human rights practitioners must take note of critiques and challenges, and be willing to adapt existing practices and theories to address criticisms. This section will examine, and aim to address, the most popular critiques raised against the human rights agenda. It will demonstrate that human rights provide the most appropriate and effective framework for development programming. As will be noted, most of the critiques come from proponents of colonial, postcolonial, postmodernist, and critical theory. ${ }^{50}$ The first part of this section will focus on critiques against how the human rights agenda is implemented and operates, whereas the second section will examine criticisms raised against the normative content of human rights.

\subsection{Critiques against the operational value of human rights}

After the Second World War, the creation of an explicit human rights framework, with a monitoring body mandated to ensure international peace and security, was considered to be the only way to not repeat the atrocities committed during the Holocaust. Accordingly, the UDHR was adopted by the UN General Assembly (UNGA) on 10 December 1948. It is argued that the UN "provides the overarching institutional framework within which contemporary development takes place". ${ }^{51}$ However, since its adoption, the achievement of the values contained in the Declaration proved to be challenging. The ensuing section will explore the arguments that have been raised as to why the protection, promotion and realisation of the multitude of rights contained in the Declaration and other human rights instruments have not been achieved.

\subsubsection{Universalism critique}

The 'universalism critique', including that of 'cultural relativism', is one of the main arguments against human rights. This critique holds that human rights, as contained in the UDHR, dictates liberal, Western values, and no space is allowed for 'multi-culturalism', 'relativism', or 'contextualism'. ${ }^{52}$ It is argued that, as a product of the Enlightenment era, the human rights framework is inevitably contextualised within an essentially Western and modernist framework. ${ }^{53}$ Moreover, very few Southern or Eastern countries had a place at the table when the content of the UDHR was decided upon. As a result, the Declaration does not properly reflect either African or

48 Darrow \& Tomas 2005:536.

49 Freeman 2011:5, 206.

50 Golder 2014:97-98; Langford et al. 2013b:25-26; Mutua 2007:554.

51 Hopper 2012:7.

52 Brown 1997:54. See also Mutua 2007:575; Vandemoortele 2013:58; Cistelecan 2011:2; Oyekan 2012:143-144; Hopgood 2013:19; Habibi 2007:7.

53 Ife 2008:5. For a full analysis of this argument, see Freeman 2011:119-155. 
Asian values. ${ }^{54}$ Even though the popular belief is that human rights are the highest moral norm, in reality clashes between human rights values with traditional practices, beliefs and religions are very common..$^{55}$ It must then be asked whether human rights are indeed "intersubjectively rooted in shared social practices" and sufficiently understood and supported by all to form an international bill of rights that is universally applicable. ${ }^{56}$

However, the mere fact that Western countries were at the forefront when the values contained in the UDHR were decided upon does not automatically limit their acceptance by communities from other regions of the world. Various other conceptions such as 'democracy', 'justice', 'freedom', 'equality', and 'human dignity', which are used frequently in national and international debate and which emerged from the Enlightenment era, are widely accepted despite their Western roots. Even though the cultural aspect of human well-being is of utmost importance, we cannot merely dismiss the value of all of the ideas listed above simply because of their origins, including that of human rights. ${ }^{57}$ Moreover, according to Rawls, there is "substantive agreement [a type of "overlapping consensus"]" across all different cultural and religious communities about what rights need to be protected and realised in order to ensure that which is deemed as the "good life". ${ }^{58}$ According to Ife, "[t]he task is to loosen them from the shackles of western modernity and to reconstruct them in more dynamic, inclusive and cross-cultural terms". ${ }^{59}$ Concepts of human dignity and worth, the notion that everyone should be treated according to a certain minimum standard, and ideas regarding respect for others are included in a number of other religious, philosophical, and cultural ideologies, including Judaism, Islam, Buddhism, Hinduism, and Christianity, as well as in Greek, Arabic, and Indian philosophy.$^{60}$ According to Ife, the best way to deal with "cultural relativism" is to critically explore the value of human rights under all cultural traditions and how they are contextualised across the different cultures. In addition, it is important to bear in mind that violations of human dignity are a global phenomenon. ${ }^{61}$ Ife goes further and takes an idealistic view in arguing that the idea of Western dominance over human rights should be viewed in a positive light. It provides human rights practitioners with the opportunity "to undertake a task of reconstruction of human rights in such a way that does not privilege the apparently dominant western world-view". ${ }^{62}$ This will, however, require a holistic understanding of human well-being and a postmodernist break from Enlightenment modernity. ${ }^{63}$ Furthermore, even though human rights

54 For example, the rights to self-determination and collective development.

55 Darrow \& Tomas 2005:537.

56 Gauri \& Gloppen 2012:496.

57 See Ife 2008:69-70.

58 As argued in Cruft et al. 2015b:21.

59 Ife 2008:5.

60 Miller 2015:7.

61 Ife 2008:69.

62 Ife 2008:70.

63 Ife 2008:167, 224-225. 
are regarded as universal values, they find application in local contexts. ${ }^{64}$ Ultimately, people who have accorded human rights to themselves which have become binding "through a process of consensus-building". ${ }^{65}$

It can thus be argued that human rights is indeed a universally accepted concept, in so far is it relates to the advancement of human well-being through development, equality and the protection of dignity. By adhering to the principles of inclusive participation and the use of local knowledge, as required under a HRBAD, human rights principles and standards can be adapted to local contexts and cultures, thereby moving away from the idea that they are enforced upon communities. Through a process of participation, human rights can be made adaptable to any local reality in as far as it does not violate the minimum standards equated to certain rights in international human rights instruments, thereby providing a much needed legal and universally accepted framework on what constitutes human well-being, upon which development can be based. However, it should be cautioned that the dominance of civil and political rights over other types of rights reinforces the argument of Western dominance over the human rights framework. ${ }^{66}$ Ife cautions that a conceptually strong human rights framework that is relevant in a world characterised by diversity should not ascribe a higher status to certain types of rights over others. ${ }^{67}$

\subsubsection{Inability to take account of practical limitations and challenges}

Another criticism views human rights as moral idealism that fails to take account of realistic limitations and challenges. ${ }^{68}$ It is argued that practical problems in ensuring adherence to human rights standards (for example, limited resources and lack of capabilities) are often overlooked. ${ }^{69}$ This is not true, as the UN International Covenant on Economic, Social and Cultural Rights, including the Limburg principles, take note of these limitations and make provision for this by calling for the progressive realisation of certain rights in accordance with the available resources of the state. ${ }^{70}$ The latter is, however, conditioned on sustaining a minimum level of fulfilment as provided for in UN treaty documents, General Comments and authoritative interpretations of rights by UN Special Procedures. ${ }^{71}$

64 Ife 2008:145.

65 Offenheiser \& Holcombe 2003:277.

66 This is due to the fact that, during the Cold War, civil and political rights (commonly referred to as first-generation rights) was advocated for by Western countries as being more important than economic and social rights (commonly referred to as second-generation rights) as advocated for by the Soviet Union.

67 Ife 2008:38.

68 De Beco 2010:267; Gready 2008:735.

69 Habibi 2007:7.

70 UNGA 1966:art 2; UN Commission on Human Rights 1987:paras 21-24.

71 See, for instance, UN Committee on Economic, Social and Cultural Rights 1999:par. 57. 
Related to this argument is the inability of the human rights framework to prioritise the achievement of one right over another. ${ }^{72}$ Setting priorities and making compromises are essential in a reality where resources and capacities are limited. ${ }^{73}$ Development agencies are likely to dismiss any approach that does not take account of the practical challenges in implementation. ${ }^{74}$ The principle of interdependence and indivisibility of rights can be misunderstood to disallow this. ${ }^{75}$ This critique is unfounded, as the human rights framework indeed allows the prioritisation of rights, but only where certain conditions relating to procedural fairness in priority-setting are met. Under the human rights framework, priorities can be set only when other rights will not be violated or regressed on in the advancement of others and, as mentioned earlier, a minimum level of all rights is sustained. ${ }^{76}$ The human rights framework also makes provision for key rights whose fulfilment will aid in guaranteeing the enjoyment of other rights and which should be addressed as a matter of priority such as, for example, the right to education, which can contribute to the fulfilment of the right to food, health, work, and so on. ${ }^{77}$ Compared to the capabilities and other development approaches, a HRBAD is realistic in its expectations by taking into account practical limitations on development, while simultaneously obliging all development actors to work towards attaining the highest standard of living for all.

\subsubsection{Inherent discriminatory nature}

It is argued that the human rights agenda is inherently discriminatory in its application of human rights principles across the world. The international human rights community will focus all its attention on one area, whilst ignoring other more serious violations. They usually prefer to focus on mass atrocities and grave violations of human rights and not on everyday oppressive structures and practices that affect millions more people. ${ }^{78}$ It is further argued that existing power hierarchies determine the choice of rights and/or groups to be protected. ${ }^{79}$ Under existing UN structures, there is hardly any opportunity for powerless individuals to have their say, thus reinforcing the elitist nature of the human rights framework. ${ }^{80}$ Some perceive the prevailing human rights agenda as set by westernised international NGOs and academics, with no influence from developing

72 Mitlin \& Hickey 2009:11; Langford et al. 2013b:26; Vandemoortele 2013:55; De Beco 2010:267; Habibi 2007:7; Flynn-Schneider 2014:1; Alston 2005:802; Von Engelhard 2010:1137; Alston 2004:par. 109.

73 Alston 2005:807; Alston 2004:par. 121; Moser et al. 2001:14; Malone \& Belshaw 2003:87; Domínguez Redondo 2009:37; UNDP 2006:26-27; Flynn-Schneider 2014:1.

74 Alston 2004:par. 122.

75 Alston 2005:807.

76 Flynn-Schneider 2014:1; Langford et al. 2013b:26.

77 UNDP 2006:26; Flynn-Schneider 2014:1.

78 Habibi 2007:3, 8-11; Hopgood 2013:173; Gready 2008:735.s

79 Alston 2005:806.

80 Ife 2008:144-145. 
countries located elsewhere. Influential international organisations such as Amnesty International and Human Rights Watch are the gatekeepers to what issues are put on the international agenda, sometimes to the detriment of smaller local organisations. ${ }^{81}$ It is also important to bear in mind that it took a long time for these organisations to include advocating for the fulfilment and protection of socio-economic rights in their own agendas. ${ }^{82}$

However, the South is gaining increasingly more power in the international human rights arena. They have ever-growing opportunities to have their say and influence where the international community choses to focus its resources. ${ }^{83}$ Furthermore, it must be borne in mind that limitations of resources and capabilities also exist at the international level and that priority must be given to certain areas. Under the HRBAD, the principles of empowerment, non-discrimination and participation of all is of fundamental value, irrespective of the level of decision-making. However, these principles are not automatically employed, and it is the obligation of human rights and development actors to ensure that the interests of all are considered. When strong international human rights organisations partner with local and grassroots organisations, they give developing countries more power to influence priority decision-making. This can act as a safeguard to ensure that the most vulnerable and marginalised are not forgotten. Moreover, activists can play a crucial role in getting the voice of the people heard by linking similar community networks in different countries and creating powerful networks between local agencies and global partners. ${ }^{84}$

\subsubsection{The ineffectiveness of human rights enforcement mechanisms}

The effectiveness of human rights enforcement mechanisms has also been questioned..$^{85}$ This is mostly because states, tasked with the fulfilment and protection of rights, are the same actors who decide on accountability and enforcement mechanisms. ${ }^{86}$ It makes sense to argue that states will be reluctant to allocate sufficient resources and attention to a well-functioning system that will only work to scrutinise their actions. Moreover, respect for sovereignty and the right to self-determination remain a key aspect of international human rights law, which limits the obligations states are willing to take on. ${ }^{87}$ Protection of state interests can easily be offered as reason for failures to fulfil rights or to take on new obligations. ${ }^{88}$ Civil and political rights are increasingly violated in the name of sovereignty and, in

81 Hopgood 2013:172.

82 Hopgood 2013:111, 145. See also Freeman 2012:147.

83 Rist 2008:140.

84 Ife 2008:144-145.

85 Schaaf 2013:49-53

86 Habibi 2007:7; Hopgood 2013:1. See also Brown 1997:53; Mutua 2007:578, 613.

87 Brown 1997:54; Mutua 2007:573, 603; Freeman 2011:157.

88 Mutua 2007:573, 613. See also De Beco 2010:273-277. 
some instances, state religion, with the human rights community unable to do anything about it. ${ }^{89}$ The latter can be linked to the critique against the universality of human rights, where human rights principles do not accord with the principles of state-enforced religions. However, this critique is, to a large extent, applicable to civil and political rights and will only affect development, based on a HRBAD, in so far as a violation of civil and political rights impedes the realisation of socio-economic rights. This can happen where it is state law and practice to view certain groups of people as unworthy of possessing any kind of right, whilst being prevented from sharing in the nation's growth and wealth. A clear example of this is India's caste system.

In answer to this challenge, UN Special Procedures and various treaty monitoring bodies were created and have so far been able to increase the legal force of rights where justiciability has been unclear and to extend the ability of the UN to deal with international and national nonstate actors. ${ }^{90}$ Moreover, political pressure, economic sanctions and trade conditionalities can be employed as tools to move states to adhere to existing obligations, rectify violations, and take on new commitments. However, other problems continue to exist. International treaty monitoring bodies can only give recommendations on state action and not legally force governments to abide by them, whilst national accountability measures can be inaccessible to poor, vulnerable and marginalised groups. ${ }^{91}$ For this reason, it is argued that, to date, the human rights agenda has been unable to effectively address structural power inequalities. ${ }^{92}$ This might be true at the global level, but grassroots activists are fighting every day to dismantle oppressive social structures and practices, challenge discriminatory traditions and beliefs, and empower those on the lower end of the power spectrum. Small successes are continuously achieved, with the influence of those standing up for transformation ever growing.

With its limited strengths, the human rights framework does indeed carry with it a powerful political and legal accountability framework at national and international level. Where development goals are formulated in terms of human rights obligations, the full force of the national and international human rights accountability framework is brought into development programming. In addition, innovative ways of holding duty bearers accountable in terms of their obligations are continuously explored. For example, in the well-known Grootboom case,,$^{93}$ the Constitutional Court of South Africa was able to order the Government to adhere to its duties under the right to adequate housing.

89 See Hopgood 2013:154.

90 Domínguez Redondo 2009:38.

91 UNDP 2006:27.

92 Golder 2014:101.

93 Government of the Republic of South Africa and Others v Grootboom and Others (CCT11/00) [2000] ZACC 19. 


\subsubsection{Justiciability of second-generation rights}

As mentioned earlier, the justiciability of economic, social and cultural rights, especially the notion of progressive realisation of rights, has received considerable scrutiny over the years. ${ }^{94}$ It is argued that it is extremely difficult to measure the achievement of these kinds of rights and that no benchmark is set against which to measure progress. ${ }^{95}$ However, as stated earlier, many courts have interpreted human rights obligations in such a manner as to create legally binding development goals. ${ }^{96}$ Human rights are increasingly understood in a comprehensive manner, containing both negative and positive rights. ${ }^{97}$ Unfortunately, socio-economic rights are continuously viewed as secondary to civil and political rights, and many states are not committed to their achievement. ${ }^{98}$ Advocating for their achievement is difficult and holds several risks for the continued financial existence of NGOs who rely on donor funding conditioned on specific political agendas. ${ }^{99}$ However, with an increasing number of national and international NGOs taking up the cause of these rights, their advancement will surely increase. ${ }^{100}$ Furthermore, it is essential to bear in mind that, if various second- (and even third-) generation rights such as, for example, the right to food, health, a healthy environment, and so on are not met, it will be impossible to fulfil and protect many civil and political rights. ${ }^{101}$

\subsubsection{Disadvantages of the political dimension of human rights}

Linking development to human rights brings development deeper into the political arena. Human rights language is regarded as an expression of political claims. ${ }^{102}$ However, being part of the global political system, impacted by international economic factors, can have various negative consequences for both human rights and development. ${ }^{103}$ In many instances, states ratify human rights instruments due to political pressure, rather than an expression of their moral duties. Even NGOs fighting for the protection of human rights have to take part in the political chess

94 De Beco 2010:273-278; Mutua 2007:622; Nelson 2007:2044; Domínguez Redondo 2009:37.

95 Nelson 2007:2044; Vandemoortele 2013:56; Freeman 2011:180-181.

96 Domínguez Redondo 2009:37. See, for instance, Minister of Health and Others v Treatment Action Campaign and Others (No 2) (CCT8/02) [2002] ZACC 15; Government of the Republic of South Africa and Others $v$ Grootboom and Others (CCT11/00) [2000] ZACC 19.

97 Langford et al. 2013b:22.

98 Mutua 2007:622; Alston 2004:par. 15.

99 Veneklasen et al. 2004:21.

100 Alston 2004:par. 15.

101 Cruft et al. 2015b:29.

102 Freeman 2011:86; De Beco 2010:268.

103 Habibi 2007:8; Mutua 2007:573-574; Archer 2009:23. 
game. Moreover, international politics is dominated by realism theory, ${ }^{104}$ which focuses on power and state interests, rather than on moral and ethical issues of human rights under the idealist tradition. ${ }^{105}$ Decisions on development and human rights can be impacted and even trumped by other factors such as security concerns, competition over resources, economic advantage, trade agreements, competing rights or groups of rights holders, and so on. ${ }^{106} \mathrm{~A}$ strong political will is also essential, in order to ensure the full recognition and realisation of rights in the national context. It is further argued that human rights can be misused as a vehicle for enforcing a 'hidden political agenda'. ${ }^{107}$ The work of the UN and other international human rights organisations has been heavily critiqued for being directed by 'power politics' instead of human rights, with nation blocks or coalitions ganging up on individual states. ${ }^{108}$ Moreover, national and international NGOs are affected by donor politics, while UN bodies such as UN Women must meet the requirements of funding states. ${ }^{109}$ However, this political character can also be beneficial for development as intense political pressure in the international arena can help protect and fulfil human rights. ${ }^{110}$

The above can be linked to the argument that the UN faces a severe lack of democracy within its organisation and subdivisions. For instance, the UN Security Council is, to a large extent, controlled by its permanent members. ${ }^{111}$ However, strong international NGOs such as Amnesty International and Human Rights Watch are aware of these power politics and can assist smaller states in advocating for their concerns, as mentioned earlier. New actors such as the Word Bank, intergovernmental organisations, as well as international and national NGOs have also incorporated human rights in their work. This has led to human rights focussing not only on the relationship between the individual and the state, but also on new kinds of relationships and partnerships between governments and development actors that can push for the fulfilment of human rights within these relationships. ${ }^{112}$

104 Political realism is a "theory of political philosophy that attempts to explain, model, and prescribe political relations. It takes as its assumption that power is (or ought to be) the primary end of political action, whether in the domestic or international arena" (Internet Encyclopaedia of Philosophy).

105 Freeman 2011:8, 156. The idealist approach holds that "old, ineffective and harmful modes of behaviour i.e., war, use of force and violence should be abandoned in favour of new ways and means as determined by knowledge, reason, compassion and self-restraint" (Yourarticlelibrary).

106 Veneklasen et al. 2004:4; Hopgood 2013:3.

107 Golder 2014:100. See also Golder 2014:83.

108 Habibi 2007:8, 19. See also Hopgood 2013:3; Mutua 2007:553, 557, 581.

109 Hopgood 2013:174.

110 Freeman 2011:10.

111 Mutua 2007:606-611.

112 Gready 2008:736. 


\subsubsection{Critiques associated with the language of human rights}

It is argued that those who need its protection the most often find it difficult to understand the language of human rights. It is viewed as an elitist term that only belongs to a powerful few. Many communities are either unsure of the meaning of human rights, or even unaware of its existence. ${ }^{113}$ Once again, grassroots organisations and national human rights institutions play an important and indispensable role in making human rights accessible to all. Building the necessary capacities of rights holders, as required under a HRBAD, will further ensure that they are empowered to claim their rights.

Another important critique related to the language of human rights holds that references to rights in public discourse continue to be narrowly conceived, and are incapable of taking account of all the challenges faced by those whose rights are violated. The use of a limited conception of rights occurs, despite the expansive interpretations and guidelines given by human rights monitoring bodies and UN Special Procedures. ${ }^{114}$ Moreover, many argue that the international community still has a long way to go in fully clarifying the content of all the rights contained in the UDHR, and to adapt the norms contained therein to changing circumstances. ${ }^{115}$ Narrow interpretations of rights have the added disadvantage of providing limited guidance on how to realise and protect them. ${ }^{116}$ In order for rights to be most effective in different communities and states, especially in following a HRBAD, they should be interpreted in terms of their historical, social, traditional, and religious context. ${ }^{117}$ Ignoring philosophical and cultural challenges will inhibit the realisation of rights and in building agencies to claim rights. ${ }^{118}$ Moreover, strict legalistic approaches that do not take account of peoples' needs and circumstances will not enable the building of proper capacities to address unequal power and social relations. This requires a proper understanding of prevailing political processes. ${ }^{119}$

However, when the principles of a HRBAD are properly implemented, development actors will be able to obtain a holistic understanding of rights and how to best ensure the fulfilment of development objectives framed in terms of rights. For example, by ensuring the participation of all community members, affected by a proposed development project, in the formulation and implementation of development objectives, practitioners are in a better position to identify challenges that can be met in the realisation of goals, as well as any inequalities and discriminatory practices that can impede development success reaching all, including the most vulnerable in society. It is also argued that the protection that human rights can offer is restricted to the elite, those in society capable of demanding its

113 Kindornay et al. 2012:495; Ife 2008:146-147.

114 Ely Yamin 2008:46.

115 Habibi 2007:7; Mutua 2007:620.

116 Gready 2008:739.

117 Brown 1997:58; Langlois 2003:521; Vandemoortele 2013:57.

118 Brown 1997:59.

119 Veneklasen et al. 2004:7; De Beco 2010:274. 
enforcement. For instance, Wing argues that, even where legal reformation of discriminatory laws is achieved, resultant equality and justice are not always assured. This is especially the case where redress mechanisms are difficult to access or where weak accountability measures are still in place. ${ }^{120}$ In support of her argument, which she refers to as the "fallacy of legalism", Wing quotes Joreiman:

Creation of law may be necessary, difficult, and challenging, but it is ultimately insufficient to achieve social change; enforcement is what enlivens law and moves it from printed word to public space. ${ }^{121}$

However, grassroots organisations and national institutions must ensure that human rights are brought to all and build the capacities of communities to understand and demand their rights.

\subsubsection{Limited contributions from other related disciplines}

It is critiqued that only focussing on achieving technical legal changes to further the protection of human rights, such as stronger legal protection or constitutional reform, can come at the cost of advocating for social justice. ${ }^{122}$ In the past, law was perceived as the primary mechanism for human rights protection, with the focus of literature on the analysis of human rights legislation, treaties and conventions. Unfortunately, limiting the human rights framework in this manner limits the scope of its value in practice, as it leaves a variety of other professionals such as social and community workers disempowered. ${ }^{123}$ Moreover, the majority involvement of lawyers has added to the degree of dominance that civil and political rights carry over other types of rights. As a result, fundamental areas of human rights concern can easily be overlooked. ${ }^{124}$ It is further argued that legal human rights discourse can claim the space of other more effective tools of achieving social justice such as local traditions, religions, and so on. ${ }^{125}$ This is especially the case in communities governed by customary law with a mistrust or lack of clear understanding of externally imposed human rights values. Addressing human rights violations in terms of a language more relevant to these communities can, in some instances, ensure greater success than the legal language of rights, for example by appealing to religious values, to which the community subscribes, that are also in accordance with recognised human rights standards.

However, it is essential to point out that law and politics are not the only characteristics of human rights. It should be viewed as a multidisciplinary concept with influences from other social sciences. ${ }^{126}$ At present, the human

120 See Wing 2012:505.

121 Wing 2012:506.

122 Veneklasen et al. 2004:19.

123 Ife 2008:29.

124 Ife 2008:29-30, 36.

125 Golder 2014:82.

126 Freeman 2011:4, 13. 
rights discourse is becoming increasingly interdisciplinary in nature, with professionals from a number of other disciplines such as, for example, sociology, economics, journalism, and so on joining in the debate. This provides a more holistic view of human rights and the deep-rooted causes of human rights abuses. Freeman argues in favour of a postmodernist approach, whereby the contributions of scholars of disciplines other than law are taken into account. ${ }^{127}$ This is necessary if human rights want to "remain an authentic discourse within which human needs, aspirations and visions can be articulated". ${ }^{128}$ As a multidisciplinary approach to human rights grows, so will the contributions from other disciplines on the relationship between development and human rights. Gaining insights from other disciplines has the advantage of obtaining a holistic and wellrounded understanding of what constitutes human development and wellbeing and how best it is to be achieved.

\subsubsection{Impact of globalisation}

Under globalisation, new emerging networks of power that transcend national boundaries can pose a significant threat to human rights. ${ }^{129}$ This includes an increase in the transfer of power from states to powerful private economic actors. ${ }^{130}$ According to Beitz, "human rights are defined as those individual interests whose protection is distinctly a matter 'of international concern' - as opposed to a merely internal, intra-state matter". ${ }^{131}$ If this view is to be followed, the impact of globalisation on the human rights framework is of concern. One of the main arguments in this respect holds that, "while corporations have grown in global power and influence, the political discourse of rights has not responded to address this". ${ }^{132}$ Globalisation causes the role of the state to weaken, which, in turn, impacts on the governments' ability to not only fulfil their human rights obligations, but also be held responsible for any failures. This growing threat can cause a "roll-back" of human rights norms. ${ }^{133}$ Globalisation has been linked to increasing inequality and poverty levels, and consequent violations of economic and social rights, especially in terms of labour rights. ${ }^{134}$ Developing states are held captive by the economic benefits that powerful international privately owned companies operating within their borders can bring to the country as a whole. ${ }^{135}$ This leaves the marginalised in society vulnerable to any human rights violations these companies choose to commit such as, for instance, internal displacements. It thus

127 Freeman 2011:13.

128 Ife 2008:50.

129 Ife 2008:21.

130 Ife 2008:20.

131 As quoted in Cruft et al. 2015b:6.

132 Miller 2015:10.

133 Hopgood 2013:166.

134 Freeman 2011:156.

135 Ife 2008:20. 
stands to reason that current human rights mechanisms are incapable of challenging these major shifts in power. ${ }^{136}$

However, it is argued that human rights and globalisation have a paradoxical relationship. Under globalisation, economic and social rights have gained more attention, and the focus on human rights obligations of non-state actors, especially multinational corporations, intergovernmental organisations, international financial institutions, has increased. ${ }^{137}$ Therefore, this new phenomenon has the potential not only to reduce and even eradicate, poverty, on the one hand, but it can also force states into economic obligations that can impede their human rights obligations. ${ }^{138}$ Globalisation has also affected the ability of governments to choose how to spend their money. According to Ife, globalisation has led to the erosion of the state and the human rights obligations that can be attributed to them. ${ }^{139}$ To ensure the most effective employment of a HRBAD, human rights and development actors must rely on global social responsibilities created under globalisation and the international law obligations of nonstate actors within the international economic and development arena. ${ }^{140}$ Moreover, international economic institutions such as the International Monetary Fund and the World Bank can also exert pressure on states to ensure that their advisory and financing activities address human rights violations committed within their borders. For instance, financing provided by the International Monetary Fund can be conditioned on protection and realisation of certain human rights.

\subsubsection{Lack of explicit guidelines to ensure the fulfilment and protection of human rights}

One last critique on the operational value of human rights for development holds that the human rights framework does not, in fact, provide explicit guidelines or clearly delineate responsibilities, but merely sets out normative values to strive for. ${ }^{141}$ It is argued that the UDHR is unclear on who the different duty bearers are with regard to respective rights. Moreover, no clear framework or methodology has been developed to ensure implementation of, and adherence to the UDHR. ${ }^{142}$ The same critique has also been raised against the Declaration on the Right to Development. ${ }^{143}$

However, as mentioned earlier, authoritative interpretations of rights by treaty monitoring bodies, including the General Comments of the UN Economic and Social Council and UN Special Procedures, as well

136 Miller 2015:10-11.

137 Freeman 2011:57.

138 Freeman 2011:177.

139 Ife 2008:108.

140 For a full overview of the human rights obligations of non-state actors, see Clapham 2006.

141 De Beco 2010:267-268; Gready \& Ensor 2005:9; Freeman 2011:47.

142 Habibi 2007:7.

143 Mutua 2007:563, 574, 618. 
as legislative interpretations by national courts have come a long way in clarifying the content of certain rights. Moreover, explicit standards are provided as a benchmark against which the fulfilment of rights can be evaluated and monitored. National and international human rights bodies have provided countless publications on how certain rights are to be fulfilled. ${ }^{144}$ These guidelines and the duties they impose are regularly updated to take account of changing circumstances and to address new threats to human rights. These provide a clear framework for development actors to achieve goals formulated in terms of human rights. Moreover, under a HRBAD, NGOs and activists play an essential role in identifying various duty bearers and holding them accountable. They can also assist state structures and other types of duty bearers in meeting obligations.

Although they take note of all the above critiques, many practitioners and academics still argue that a HRBAD provides the most acceptable and effective normative framework to effect the social, political, cultural and economic transformation on which success in development programming is dependent. Gauri \& Gloppen strongly state that: "[h]uman rights are probably the dominant normative conception in the contemporary globalized world". ${ }^{145}$

\subsection{The normative value of human rights}

This section focusses on some critiques raised against the normative value of human rights. Other than a short overview of the origins of human rights, this section does not provide an in-depth discussion of the philosophical foundations of human rights, including the basis of the notion of rights itself. Nor does it explore arguments raised against these foundations. To limit the scope of this examination, it is presupposed that human rights, defined as "universally recognised moral values", do indeed exist and belong to everyone based on the mere fact that they are human. ${ }^{146}$ It is, however, worth noting that:

[t]here is no consensus on the best justification for human rights, and there is no reason to expect that such a consensus can be achieved. However, the fact that there are several strong justifications for human rights strengthens the moral force of the idea. ${ }^{147}$

\subsubsection{Global acceptance of the moral value of human rights}

Since the adoption of the UDHR, the term human rights has gained global acceptance as a "distinctive legal, moral and political concept". ${ }^{148}$ People from a variety of political beliefs, cultures and ideologies accept human rights as the "highest moral standards" governing state and individual action, with

144 See, for instance, South African Human Rights Commission 2008.

145 Gauri \& Gloppen 2012:485.

146 OHCHR 2002:par. 3; Tomalin 2006:93-94.

147 As quoted in Freeman 2011:74. See also Freeman 2011:87.

148 Cruft et al. 2015b:1. 
various countries having human rights included in their constitutions. ${ }^{149}$ Other than international law, the human rights framework also "derive[s] strength and legitimacy ... from various other sources such as national law, socially acknowledged ethical principles of equity and justice, [and] from the organization and struggles of people's organizations". ${ }^{150}$ Due to its high moral status, it has been adopted by a variety of actors, including states, international organisations such as the World Bank, international corporations, as well as social and peoples' movements. ${ }^{151}$

\subsubsection{Natural law as the origin of human rights}

What we currently call human rights can be traced back to the idea of natural rights that emerged in the Enlightenment era through the work of philosophers such as Thomas Hobbes, John Locke and Jean-Jacques Rousseau. ${ }^{152}$ Under the doctrine of the Rights of Man, as posited by Thomas Paine in $1791,{ }^{153}$ it is held that, even before the formation of any type of government, individuals possessed a set of "inherent" or "natural rights" in a hypothetical "state of nature". ${ }^{154}$ As a result, "the legitimate powers of government are derived from these antecedent natural rights by means of a social contract or agreement". ${ }^{155}$ Locke and Rousseau argued that, under natural law, all human beings are free; a freedom which no one else can take away. This idea that people possess a certain set of rights merely on the basis of their humanity inspired the French Declaration of the Rights of Man and of the Citizens in 1789, which emphasised that the right to freedom is "natural, inalienable, and sacred". ${ }^{156}$ In 1791, the United States of America formally included a Bill of Rights into their Constitution, thereby giving "explicit political recognition" to the Rights of Man doctrine. ${ }^{157}$

However, several critiques have been raised against the notion of natural rights. This includes the critique by Bentham that "[t]here is no such thing as rights anterior to the establishment of government". ${ }^{158}$ According to Winston, the most influential critique came from Karl Marx who argued that the rights to freedom and equality, espoused under natural law, did little to halt the continued existence of discrimination based on economic, gender and racial status. According to Marx, true equality could only be achieved in a "'classless' society in which not only

149 Winston 1989:v.

150 Gready \& Ensor 2005:237-238.

151 Gready 2008:735-736.

152 Winston 1989:3-4. The idea of natural rights, in turn, finds its origins in the works of Aristotle and the Greek Stoics as well as in Judaism and Christianity (Winston 1989:3). See also Cruft et al. 2015b:1-5; Ife 2008:5.

153 Paine 1791.

154 Winston 1989:4.

155 Winston 1989:4.

156 Winston 1989:4.

157 Winston 1989:4.

158 As quoted in Winston 1989:5. 
political but also economic justice and equality were fully realized". ${ }^{159}$ Marx, along with Friedrich Engels, opined that the emergence of natural law reflected the interests of the up-and-coming capitalist class. ${ }^{160}$ Women and people of colour were still regarded as subhuman and were, therefore, denied the rights of man. However, times have changed, and it is widely and unanimously accepted that all human beings have an inherent human dignity, which gives them a special moral status to be the carriers of human rights. Even though remnants of past discrimination still exist in social and economic practices, this inherent dignity forms the foundation of the human rights framework. ${ }^{161}$

\subsubsection{Normative value of rights language}

The question that falls to be asked is why the use of rights is generally preferred above other terms such as "goals, duties, interests, needs, and claims". ${ }^{162}$ Rights can be defined as "just claims or entitlements that derive from moral and/or legal rules". ${ }^{163}$ Over the years, various understandings of the notion of 'rights' have been put forward, for example, as:

grounds of duties to benefit the interests of others, as claims or entitlements, as entitlements having institutional or social recognition, as constellations of powers, immunities, liberties, and claims, and as 'trumps' against considerations of general social utility. ${ }^{164}$

Each of these understandings carries with it certain advantages that rights language has to offer to development. ${ }^{165}$ Freeman argues that the ultimate benefit of the discourse of rights is the creation of a "special entitlement to press the relevant claims if enjoyment of the right is threatened or denied". ${ }^{166}$ Raz agrees that the most important feature of rights is that it "ground[s] requirements for action in the interest of other beings". ${ }^{167}$ This means that where a right and right holder exist, a corresponding duty and duty bearer also exist.

In contrast to the critiques mentioned in the previous section, the use of human rights language carries with it its own distinct advantages. On the one hand, it gives human rights organisations and actors avenues to break through oppressive structures and practices and to address their resultant inequalities, while giving development agents an opportunity to base their work on universal themes of what is right and just. ${ }^{168}$ It can be

159 Winston 1989:5.

160 Winston 1989:5.

161 Winston 1989:9.

162 Winston 1989:6.

163 Freeman 2011:7.

164 Winston 1989:10. See also Nussbaum 2000:237.

165 See Winston 1989:10-17.

166 Freeman 2011:67.

167 As quoted in Winston 1989:11.

168 Ife 2008:225-226. 
argued that law provides objective standards to use in the face of moral and political arguments against human rights, including development based on human rights. ${ }^{169}$ Moreover, human rights language provides a way of easily implementing universal themes and values in local contexts. Human rights, by its very nature, is a "discourse of hope" for the vulnerable, the marginalised, and the voiceless. ${ }^{170}$ However, it should be borne in mind that human rights terms, concepts and rights themselves are not always clear. According to Freeman,

[t]he determination of the meaning of human rights is a continuing social process that not only involves legal professionals (such as judges, UN experts and academic lawyers) but also various 'stakeholders' (such as governments, inter-governmental organizations, non-governmental organizations, non-legal academics and citizens). ${ }^{171}$

\subsubsection{Human rights as moral rights}

From a human rights perspective, rights are often linked to the notions of liberty and freedom. The primary aim of human rights is to ensure wellbeing and freedom. Freeman adds addressing the misuse of power to these aims. ${ }^{172}$ As mentioned earlier, human rights are regarded as moral rights possessed by all human beings, based on their moral status, at all times and in all places, simply because of the fact that they are human. ${ }^{173}$ Durkheim states:

[t]he speed with which human rights has penetrated every corner of the globe is astounding. Compared to human rights, no other system of universal values has spread so far so fast ... In what amounts to an historical blink of the eye, the idea of human rights has become the lingua franca of international morality. ${ }^{174}$

A moral right can be defined as "(1) the rational basis for a justified demand (2) that the actual enjoyment of a substance be (3) socially guaranteed against standard threats". ${ }^{175}$ Ife boldly states that:

[t]he idea of human rights is one of the most powerful in contemporary social and political discourse. It is readily endorsed by people from many different cultural and ideological backgrounds and it is used rhetorically in support of a large number of different and sometimes conflicting causes. ${ }^{176}$

169 Freeman 2011:8.

170 Ife 2008:227.

171 Freeman 2011:6.

172 Freeman 2011:210.

173 Cruft et al. 2015b:4.

174 As quoted in Hopgood 2013:4.

175 Shue, quoted in Winston 1989:26.

176 Ife 2008:4. 
Moreover, it provides "the fundamental moral standard by which to measure the performance of governments", which can play a particularly important role in the area of development. This is further enhanced by the visible nature of the norms to which states publicly committed themselves. ${ }^{177}$ The term moral rights, and not legal or civil rights, should be emphasised, in this instance. This means that the possession of human rights by an individual or group is not dependent on the legal recognition or protection of these rights by governments, but is capable of criticising conventional societal standards through the use of "extra-legal ethical standards". ${ }^{178}$ The international human rights framework was a result of intense political processes, after which it was codified into national and international law. ${ }^{179}$ However, the moral value of human rights steps in where rights have not been codified or cannot be legally enforced to overcome unjust legal systems. ${ }^{180}$ This is the case where citizens of authoritarian or totalitarian regimes, with a biased judiciary system, can call on international bodies for intervention, even if their state is not party to relevant treaties and conventions.

Cruft et al. provide an instrumental justification for the moral status of human rights, by arguing that they are "useful or essential means to realize or further valued features of human lives". According to them, these features include agency, a good life, and basic needs. ${ }^{181}$ However, many do not agree with this view of human rights, but rather defend a political conceptualisation of the nature of human rights, which directly challenges the elements of a moral view of human rights. ${ }^{182}$ They include Rawls, ${ }^{183}$ Beitz ${ }^{184}$ and Raz. ${ }^{185}$ The main argument, in this instance, holds that "human rights are not based on certain features of humanity; rather, the distinctive nature of human rights is to be understood in light of their role or function in modern international political practice". ${ }^{186}$ Some also argue that the wide discretion that states have in fulfilling socio-economic rights (for instance, "to take steps ... to the maximum of its available resources ... with a view to achieving progressively the full realization of the[se] rights"), ${ }^{187}$ does not make them rights at all, but rather goals that states are legally bound to pursue. ${ }^{188}$

However, states that have committed themselves to realising and fulfilling socio-economic rights, either through the ratification of treaties and conventions or by the inclusion of these rights in their national

177 Winston 1989:6. See also McInerney-Lankford 2013:163.

178 Cruft et al. 2015b:5. See also Winston 1989:7-8.

179 Freeman 2011:11, 157.

180 Freeman 2011:11, 67; Hopgood 2013:7.

181 Cruft et al. 2015b:11.

182 See Cruft et al. 2015b:6-7, 18-19.

183 See Rawls 2002.

184 See Beitz 2011.

185 See Raz 2010.

186 Cruft et al. 2015b:6.

187 UNGA 1966:art. 2.

188 Cruft et al. 2015b:26. 
constitutions, have created a legally binding right for their citizens which, as mentioned earlier, carries with it a legally binding duty. Moreover, as indicated earlier, courts, aided by authoritative interpretations of treaty monitoring bodies and UN Special Procedures, have been able to find innovative ways to interpret the legal duties of states in terms of socioeconomic rights. Whether one accepts human rights as universal moral norms or the product of legal and political processes, the unparalleled value of human rights as a normative basis for development cannot be denied.

\subsubsection{Practical value of human rights}

Human rights cannot be analysed as an abstract concept. Its deep connection with human experiences and well-being must always be considered. ${ }^{189}$ The work of feminists has had the advantage of linking the public (role of public authorities and governments) to the personal life of all. This is essential for successful human rights practice. ${ }^{190}$ One of the major criticisms against the human rights framework is that it is mostly concentrated on the actions of actors in the public sphere. Unfortunately, human rights are often abused mostly in private daily lives. ${ }^{191}$ Therefore, it is useless to advocate for the protection of rights if the private practices that underlie systemic violations of these specific rights are not addressed. Following a structural perspective of human rights (including development under a HRBAD) has the potential to transform current systems of rights denial and/or violations. This is especially the case for second- and thirdgeneration rights where globalisation and economic necessities have been proven to be the underlying cause of unequal distribution of resources, poverty, environmental degradation, and various other rights violations.

Considering all of the concerns raised against human rights, as set out above, it is essential to highlight that:

[t]he purpose of human rights is to avert, as far as possible, the social conditions and practices that history teaches us inevitably lead to human suffering and misery ... and to create as far as possible the social conditions that are most conducive to human well-being, happiness, and flourishing. The doctrine of human rights must be considered as an evolving whole in relation to the changing political and economic conditions of human society, and, in this light, the idea of human rights can be understood as a description of a political ideal; it is a partial blueprint for the building of just and peaceful human societies and for creating a stable world order in which all persons may lead fulfilling and dignified human lives. ${ }^{192}$

Winston goes on to argue that, if we agree that "observance of the moral norms that embody the theory of human rights promote[s] the

189 Freeman 2011:3.

190 Ife 2008:38.

191 Ife 2008:52.

192 Winston 1989:38. 
development of stable and progressive societies where greater numbers of human individuals can lead productive, fulfilling and peaceful lives" provides the best and easiest justification for human rights as a good theory. He does, however, point out that, if this theory is to remain good, it must evolve to take account of new threats to basic human values. ${ }^{193}$ On the other hand, Hopgood fiercely critiques the global human rights regime, "a global structure of laws, courts, norms, and organizations that raise money, write reports, run international campaigns, open local offices, lobby governments, and claim to speak with singular authority in the name of humanity as a whole", that has dominated the past three decades. ${ }^{194} \mathrm{He}$ argues that it is the inner logic of this regime "[t]o become the supreme authority - a court of law above all politics, national and international". ${ }^{195}$ He further contends that the end has come for this type of human rights framework, as "[w]e have entered an era of multipolar authority where what is 'normal' or 'appropriate' no longer has one answer", that universal norms are fading away, and that the lack of democratic authority and the ineffectiveness of the global human rights regime is becoming evident. ${ }^{196}$ Moreover, when state powers decide to oppose this regime, its claims to moral authority, universally applied norms, and legitimacy are undermined. ${ }^{197}$ It is in these spaces that sovereigns (for example, Syria, Israel), upcoming state powers (for example, Russia, China), conservative nationalists, and religious extremists are creating their own norms that are imposed on anyone who is sufficiently vulnerable. ${ }^{198}$

In sum, Hopgood argues that the time for human rights has come and gone, especially considering the critiques associated with the global human rights regime. ${ }^{199}$ Many view the current human rights discourse as in 'crisis' and continuously facing new challenges such as, for example, retrogression in the recognition and protection of rights in certain countries, violations of civil and political rights in the name of the 'war on terror, and so on. ${ }^{200}$ Human rights are increasingly failing to offer sufficient protection. One example is the international human rights community's inability to challenge the current situation in Syria, with still no end in sight. ${ }^{201}$

However, Gready argues that human rights are not faced by a crisis, but by a paradox. Although it is facing new challenges on a daily basis,

193 Winston 1989:38-39.

194 Hopgood 2013:ix. He compares this type of Human Rights with lower case human rights, that is "the local and transnational networks of activists who bring publicity to abuses they and their communities face and who try to exert pressure on governments and the United Nations for action" (Hopgood 2013:viii).

195 Hopgood 2013:x.

196 Hopgood 2013:ix, 2, 167.

197 Hopgood 2013:xiii.

198 Hopgood 2013:1, 3, 14.

199 Hopgood 2013:vii-xv.

200 Gready 2008:735; Veneklasen et al. 2004:16.

201 Hopgood 2013:1. 
it continues to expand and redefine its meaning and function. ${ }^{202}$ Human rights aims to unite people from different cultures and backgrounds under a universal understanding of shared humanity and basic human values in the face of new threats. ${ }^{203}$ Therefore, many human rights proponents still believe that human rights provides a strong "moral reference point for those who would seek to reaffirm the values of humanity" and plays a particularly important role for those in the human services profession, especially as it relates to development. ${ }^{204}$ Moreover, people will always demand and stand up for the right to be treated with a certain level of respect and to live a dignified live. Accordingly, there can never be an end times to these types of human rights. ${ }^{205}$

\section{Conclusion}

The HRBAD emerged in the1990s, and has since been increasingly accepted by the UN, other international and inter-governmental organisations, states, as well as by national human rights and development organisations and actors. The ultimate objective of a HRBAD is the promotion of human well-being, through the realisation of human rights. Under this approach, international human rights norms, standards and principles form the foundation of development programming. This approach was also proposed as the answer to rectify some of the failings of the 2000 MDG framework. This article aimed to explore and analyse the operational and normative critiques that have been raised against the human rights framework, as the foundation of this approach.

Many critiques have been raised against the ability of the human rights framework to be implemented in practice. It was also shown that continuously emerging threats challenge the operational value of human rights. However, the framework has proven to be adaptable to these challenges. Practitioners and scholars are continuously working towards overcoming practicalities that impede the achievement of the protection and realisation of the human rights of all. It was shown that human rights are viewed as universal moral values with distinctive legal, moral, and political components. The moral authority of human rights is based on the notion of natural rights, which emerged during the Enlightenment era. Moreover, human rights values are intricately linked to the notions of human dignity and well-being, which is strived for under a variety of political beliefs, cultures and ideologies. Even though a number of critiques have been raised against the moral standing of human rights, it was demonstrated that these values have been universally accepted as the highest moral authority.

It was also shown that the use of rights language in lieu of other concepts such as goals, duties, interests, needs, and claims holds

202 Gready 2008:736-737.

203 Ife 2008:6, 10.

204 Ife 2008:1.

205 Hopgood 2013:viii. 
several benefits. Various understandings of rights and the benefits they hold was offered in answer to this, the most important of which is the correlation between rights and duties: where there is a right holder, there is a corresponding duty bearer. Through the use of human rights language and linking the public to the private sphere, oppressive structures, discriminatory practices and inequalities can be addressed to the benefit of development programming. Moreover, it provides the opportunity for development actors to base programming on values that are right and just.

Although the human rights framework faces numerous critiques, it still carries the weight of the highest moral values in present times, and it provides a solid foundation on which to base development programming. Critiques and challenges raised against the human rights framework are continuously addressed and adapted to, in order to ensure the protection of the rights of all. Long and difficult struggles have led to the legitimisation of the human rights framework. However, the fight is not over, as daily human rights violations call for a continuous battle to afford everyone the possibility to have their human rights respected, protected and fulfilled.

\section{Bibliography}

\section{ALSTON P}

2004. A human rights perspective on the Millennium Development Goals.

Paper prepared as a contribution to the work of the Millennium Project Task

Force on Poverty and Economic Development. http://pacific.ohchr.org/

docs/A_HR_perspective_on_MDGs_P_Alston.doc (accessed on 25 May 2018).

2005. Ships passing in the night: The current state of the human rights and development debate seen through the lens of the Millennium Development Goals. Human Rights Quarterly 27(3):755-829.

\section{ANAN K}

2000. We the peoples: The role of the United Nations in the $21^{\text {st }}$ century. New York: United Nations.

\section{ANONYMOUS}

2013. Marking anniversary of historic conference, UN urges stronger implementation of human rights. United Nations News Centre. 25 September. http://www.un.org/apps/news/story.asp?newsid=46009\#.u8y8zjssw04 (accessed on 25 May 2018).

\section{ARCHER R}

2009. Linking rights and development: Some critical challenges. In S Hickey \& D Mitlin (EDS.) 2009:21-30.

\section{ARNDT H}

2008. Economic development: A semantic history. In S Chari \& S Corbridge (EDS.) 2008:51-57.

\section{BEITZ CR}

2011. The idea of human rights. Oxford: Oxford University Press.

\section{BESSON S \& TASIOULAS J (EDS.)}

2010. The philosophy of international law. Oxford: Oxford University Press. 


\section{BHOURASKAR D}

2013. United Nations development aid: A history of UNDP. New Delhi: Academic Foundation.

\section{BRADLOW DD}

2004. Development decision-making and the content of international development law. Boston College International Comparative Law Review 24(2):195-217.

\section{BROWN C}

1997. Universal human rights: A critique. The International Journal of Human Rights 1(2):41-65.

\section{CHARI S \& CORBRIDGE S (EDS.)}

2008. The development reader. Abingdon: Routledge.

\section{CISTELECAN A}

2011. Which critique of human rights? Evaluating the post-colonialist and the post-althusserian alternatives. International Journal of Žižek Studies 5(1). http://zizekstudies.org/index.php/IJZS/article/view/391/398 (accessed on 25 May 2018).

\section{CLAPHAM A}

2006. Human rights obligations of non-state actors. Oxford: Oxford University Press.

\section{CORNWALL A \& NYAMU-MUSEMBI C}

2004. Putting the 'rights-based approach' to development into perspective. Third World Quarterly 25(8):1415-1437.

\section{CRUFT R, MATTHEW LIAO S \& RENZO M (EDS.)}

2015a. Philosophical foundations of human rights. Oxford: Oxford University Press.

2015b. The philosophical foundations of human rights: An overview. In R Cruft et al. (EDS.) 2015a:1-41.

\section{DARROW M \& TOMAS A}

2005. Power, capture, and conflict: A call for human rights accountability in development cooperation. Human Rights Quarterly 27(2):471-538.

\section{DE BECO G}

2010. The interplay between human rights and development the other way around: The emerging use of quantitative tools for measuring the progressive realisation of economic, social and cultural rights. Human Rights and International Legal Discourse 4(2):265-287.

\section{DOMÍNGUEZ REDONDO E}

2009. The Millennium Development Goals and the human rights-based approach: Reflecting on structural chasms with the United Nations system. The International Journal of Human Rights 13(1):29-43.

\section{DOUZINAS C}

2000. The end of human rights: Critical legal thought at the turn of the century. Oxford: Hart Publishing. 


\section{ELY YAMIN A}

2008. Will we take suffering seriously? Reflections on what applying a human rights framework to health means and why we should care. Health and Human Rights 10(1):45-63.

\section{FILMER-WILSON E}

2005. The human rights-based approach to development: The right to water. Netherlands Quarterly of Human Rights 23(2):213-241.

\section{FLYNN-SCHNEIDER A}

2014. Inter-governmental organizations. Human Rights Brief 21(1). http:// digitalcommons.wcl.american.edu/cgi/viewcontent.cgi?article $=1906 \&$ context= hrbrief (accessed on 25 May 2018).

\section{FREDIANI AA}

2010. Sen's capability approach as a framework to the practice of development. Development in Practice 20(2):173-187.

\section{FREEMAN M}

2011. Human rights: An interdisciplinary approach. Cambridge: Polity Press.

\section{FUKUDA-PARR S, ELY YAMIN A \& GREENSTEIN J}

2014. The power of numbers: A critical review of Millennium Development Goal targets for human development and human rights. Journal of Human Development and Capabilities: A Multi-Disciplinary Journal for PeopleCentered Development 15(2-3):105-117.

\section{GAURI V \& GLOPPEN S}

2012. Human rights-based approaches to development: Concepts, evidence and policy. Polity 44(4):485-503.

\section{GLENDINNING TC}

2013. Book review: Millennium Development Goals: Looking beyond 2015. African Review of Economics and Finance 4(2):300-304.

\section{GOLDER B}

2014. Beyond redemption? Problematising the critique of human rights in contemporary international legal thought. London Review of International Law 2(1):77-114.

\section{GREADY $P$}

2008. Rights-based approaches to development: What is the value-added. Development in Practice 18(6):735-747.

\section{GREADY P \& ENSOR J}

2005. Reinventing development: Translating rights-based approaches from theory into practice. London: Zed Books.

\section{HABIBI DA}

2007. Human rights and politicized human rights: A utilitarian critique. Journal of Human Rights 6(1):3-35.

HICKEY S \& MITLIN D (EDS.) 2009. Rights-based approaches to development: Exploring the potential and pitfalls. Sterling: Kumarian Press.

\section{HOPGOOD S}

2013. The endtimes of human rights. New York: Cornell University Press. 
HOPPER P

2012. Understanding development: Issues and debates. Cambridge:

Polity Press.

IFE J

2008. Human rights and social work. Towards rights-based practice. Revised edition. Cambridge: Cambridge University Press.

INTERNET ENCYCLOPAEDIA OF PHILOSOPHY

Political realism. http://www.iep.utm.edu/polreal/ (accessed on 6 October 2017).

\section{JACKSON P}

2007. A prehistory of the Millennium Development Goals: Four decades of struggle for development in the United Nations. United Nations Chronicle $\operatorname{XLIV}(4): 7-9,43$.

JOINT STATEMENT FROM 332 CIVIL SOCIETY ORGANISATIONS 2013. Human Rights for All Post-2015. 10 December. https:// sustainabledevelopment.un.org/content/documents/5123joint.statement. dec10.pdf. (accessed on 26 September 2018).

\section{KINDORNAY S, RON J \& CARPENTER C}

2012. Rights-based approaches to development: Implications for NGOs. Human Rights Quarterly 34(2):472-506.

\section{KNOX JH}

2015. Human rights, environmental protection, and the Sustainable Development Goals. Washington International Law Journal Association 24(3):517-536.

\section{LANGFORD M, SUMNER A \& YAMIN AE (EDS.)}

2013a. The Millennium Development Goals and human rights: Past, present and future. New York: Cambridge University Press.

2013b. Introduction: Situating the debate. In M Langford et al (EDS.) 2013a:134.

\section{LANGLOIS AJ}

2003. Human rights and modern liberalism: A critique. Political Studies 51(3):509-523.

\section{LUNDSTRÖM SARELIN A}

2007. Human rights-based approaches to development cooperation, HIV/AIDS, and food security. Human Rights Quarterly 29(2):460-488.

\section{MACNAUGHTON G \& FREY DF}

2016. Decent work, human rights and the Sustainable Development Goals. Georgetown Journal of International Law 47(2):607-663.

\section{MALONE M \& BELSHAW D}

2003. The human rights-based approach to development. Transformation 20(2):76-89.

\section{MCINERNEY-LANKFORD S}

2013. International development actors and human rights. In M Langford et al. (EDS.) 2013a:160-206. 


\section{MIDGLEY $J$}

2014. Social development: Theory and practice. London: Sage.

\section{MILLER H}

2010. From 'rights-based' to 'rights-framed' approaches: A social constructionist view of human practice. The International Journal of Human Rights 14(6):915-931.

2015. Rejecting 'rights-based approaches' to development: Alternative engagements with human rights. Journal of Human Rights. http://dx.doi.org/10 $.1080 / 14754835.2015 .1103161$ (accessed on 25 May 2018).

\section{MITLIN D \& HICKEY S}

2009. Introduction. In S Hickey \& D Mitlin (EDS.) 2009:1-19.

\section{MOKHIBER CG}

2001. Toward a measure of dignity: Indicators for rights-based development. Statistical Journal of the United Nations Economic Commission for Europe 18(2-3):155-162.

MOSER C \& NORTON A, WITH CONWAY T, FERGUSON C \& VIZARD P 2001. To claim our rights: Livelihood security, human rights and sustainable development. London: Overseas Development Institute.

\section{MUTUA M}

2007. Standard setting in human rights: Critique and prognosis. Human Rights Quarterly 29(3):547-630.

\section{NELSON P}

2007. Human rights, the Millennium Development Goals, and the future of development cooperation. World Development 35(12):2041-2055.

\section{NUSSBAUM M}

2000. Women's capabilities and social justice. Journal of Human Development 1(2):219-247.

\section{NUSSBAUM MC}

2011. Creating capabilities: The human development approach. Cambridge, MA: The Belknap Press of Harvard University Press.

\section{O'DWYER B \& UNERMAN J}

2010. Enhancing the role of accountability in promoting the rights of beneficiaries of development NGOs. Accounting and Business Research 40(5):451-471.

\section{OFFENHEISER RC \& HOLCOMBE SH}

2003. Challenges and opportunities in implementing a rights-based approach to development: An Oxfam America perspective. Non-Profit and Voluntary Sector Quarterly 32(2):268-301.

\section{OPPONG RF}

2006. Trade and human rights: A perspective for agents of trade policy using a rights-based approach to development. African Human Rights Law Journal 6(1):123-145.

\section{OYEKAN AO}

2012. A critique of the distinct theory of human rights in Africa. Philosophia Africana 14(2):143-154. 


\section{PAINE T}

1791. Rights of man: Answer to Mr. Burke's attack on the French Revolution. London: JS Jordan.

\section{RAWLS J}

2002. The law of peoples: With 'the idea of public reason revisited'. Cambridge, MA: Harvard University Press.

RAZ J

2010. Human rights without foundations. In S Besson \& J Tasioulas (EDS.) 2010:321-338.

\section{RIST G}

2008. The history of development: From Western origins to global faith. London \& New York: Zed Books.

\section{SCHAAF R}

2013. Development organizations. Abingdon: Routledge.

\section{SCHMIDT-TRAUB G}

2009. The Millennium Development Goals and human rights-based approaches: Moving towards a shared approach. The International Journal of Human Rights 13(1):72-85.

\section{SOUTH AFRICAN HUMAN RIGHTS COMMISSION}

2008. The Millennium Development Goals and the realisation of economic and social rights in South Africa: A review. ESR Unit: Research, Documentation and Policy Analysis Programme Working Paper. https://www.sahrc.org. za/home/21/files/1/ESR\%20Working\%20Paper\%20for\%20Public\%20 Hearings\%202009.pdf (accessed on 26 May 2018).

\section{TOMALIN E}

2006. Religion and a rights-based approach to development. Progress in Development Studies 6(2):93-108.

\section{TSIKATA D}

2004. The rights-based approach to development: Potential for change or more of the same? Institute of Development Studies Bulletin 35(4):130-133.

\section{UNITED NATIONS (UN)}

2016. Official list of MDG indicators. https://mdgs.un.org/unsd/mdg/Host. aspx?Content=indicators/officiallist.htm (accessed on 27 September 2017).

2015. Millennium Development Goals Report. http://www.un.org/ millenniumgoals/2015_MDG_Report/pdf/MDG\%202015\%20rev\%20(July\%20 1).pdf (accessed on 26 September 2018).

\section{UNITED NATIONS COMMISSION ON HUMAN RIGHTS (UNCOHR)}

1987. Note verbale, dated 5 December 1986, from the Permanent Mission of the Netherlands to the United Nations Office at Geneva addressed to the Centre for Human Rights ('Limburg Principles') http://www.refworld.org/ docid/48abd5790.html (accessed on 26 September 2018).

\section{UNITED NATIONS COMMITTEE ON ECONOMIC, SOCIAL AND \\ CULTURAL RIGHTS (UNCESCR)}

1999. General Comment 13: The Right to Education (Article 13). http://www. right-to-education.org/resource/cescr-general-comment-13-right-educationarticle-13 (accessed on 26 September 2018). 


\section{UNITED NATIONS DEVELOPMENT GROUP (UNDG)}

2003. The human rights-based approach to development cooperation:

Towards a common understanding among UN agencies. http://hrbaportal.org/ the-human-rights-based-approach-to-development-cooperation-towards-acommon-understanding-among-un-agencies (accessed on 25 May 2018).

2006. Human rights and the Millennium Development Goals: Making the link. http://www.undp.org/content/dam/aplaws/publication/en/publications/ poverty-reduction/poverty-website/human-rights-and-the-millenniumdevelopment-goals/Human\%20Rights\%20and\%20the\%20MDGs.pdf (accessed on 25 May 2018).

\section{UNITED NATIONS DEVELOPMENT PROGRAMME (UNDP)}

1990. Human development report 1990: Concept and measurement of human development. Oxford: Oxford University Press.

2000. Human development report 2000: Human rights and human development. Oxford: Oxford University Press.

\section{UNITED NATIONS GENERAL ASSEMBLY (UNGA)}

1948. Universal Declaration of Human Rights (adopted on 10 December 1948).

1966. International Covenant on Economic, Social and Cultural Rights

(adopted on 16 December 1966 and entered into force on 3 January 1976).

1986. Declaration on the Right to Development (adopted on 4 December 1986).

1989. Convention on the Rights of the Child (adopted on 20 November 1989 and entered into force on 2 September 1990).

2000. Millennium Declaration (adopted on 18 September 2000.

2013. A Life of Dignity for All: Accelerating Progress towards the Millennium Development Goals and Advancing the United Nations Development Agenda Beyond 2015. Report of the Secretary-General. http://www.un.org/ millenniumgoals/pdf/A\%20Life\%20of\%20Dignity\%20for\%20All.pdf (accessed on 26 September 2018).

\section{UNITED NATIONS OFFICE OF THE HIGH COMMISSIONER FOR HUMAN RIGHTS (UNOHCHR)}

2002. Draft guidelines: A human rights approach to poverty reduction strategies. http://www.refworld.org/pdfid/3f8298544.pdf (accessed on 25 May 2018).

2006a. Frequently asked questions on a human rights-based approach to development cooperation. Geneva: United Nations Publications.

2006b. Principles and guidelines for a human rights approach to poverty reduction strategies. http://www.ohchr.org/Documents/Publications/ PovertyStrategiesen.pdf (accessed on 25 May 2018).

2008. Claiming the Millennium Development Goals: A human rights approach. Geneva: United Nations Publications. http://www.ohchr.org/Documents/ Publications/Claiming_MDGs_en.pdf (accessed on 25 May 2018). 


\section{UNITED NATIONS SYSTEM TASK TEAM ON THE POST-2015 UNITED NATIONS DEVELOPMENT AGENDA}

2012. Realizing the Future We Want for All. Report to the Secretary-General. http://www.un.org/millenniumgoals/pdf/Post_2015_UNTTreport.pdf (accessed on 26 September 2018).

\section{VANDEMOORTELE $J$}

2013. The limits of the MDGs' design: Six caveats for human rights. In M Langford et al. (EDS.) 2013:49-66.

\section{VAN GINNEKEN W}

2011. Social protection, the Millennium Development Goals and human rights. Institute for Development Studies Bulletin 42(6):111-117.

\section{VENEKLASEN L, MILLER V, CLARK C \& REILLY M}

2004. Rights-based approaches and beyond: Challenges of linking rights and participation. A joint initiative of the Participation Group at Institute for Development Studies and Just Associates. IDS Working Paper 235. https:// www.ids.ac.uk/files/Wp235.pdf (accessed on 25 May 2018).

\section{VON ENGELHARDT M}

2010. The Millennium Development Goals and human rights at 2010 an account of the Millennium Summit outcome. Goettingen Journal of International Law 2(3):1129-1146.

\section{WING SD}

2012. Human rights-based approaches to development: Justice and legal fiction in Africa. Polity 44(4):504-522.

\section{WINSTON ME}

1989. The philosophy of human rights. Belmont, CA: Wadsworth Publishing Company.

\section{YOURARTICLELIBRARY}

Idealism: Idealism in international relations. http://www.yourarticlelibrary. com/international-politics/idealism-idealism-in-international-relations/48471/ (accessed on 6 October 2017). 